\title{
PENGARUH LINGKUNGAN KELUARGA, SEKOLAH DAN MASYARAKAT TERHADAP PERSEPSI GENDER MAHASISWA LAKI-LAKI DAN PEREMPUAN
}

\section{(Kasus Mahasiswa Sekolah Tinggi Ekonomi Islam TAZKIA Tahun Masuk 2009)}

\author{
Rehasti Dya Rahayu ${ }^{1)}$, Winati Wigna ${ }^{2)}$ \\ 1) Mahasiswa, Departemen Sains KPM FEMA IPB, I34060396. \\ 2) Dosen Pembimbing, Departemen Sains KPM FEMA IPB, Dra, MDS.
}

\begin{abstract}
The goals of this research are to analyze family, school, and society area that influence of student gender perception and then to know the different influence factors from it. This research has done in STEI TAZKIA. Generally, even though have the high education but the gender perception is still low. This reality has different with what happened in STEI TAZKIA. STEI TAZKIA students have the high gender perception. Those facts are the good reason to do research in STEI TAZKIA.

The results of this research are student gender perceptions do not come from the family area, but student gender perception come from school and society area and there are different results from boy and girl students. The results of this research proofed that the influence boy students gender perception come from school area (from their teacher) and society area (from their friends), different with the girl students that the influence gender perception come from family area (from their mother).
\end{abstract}

Keywords: Family area, school area, and society area.

\subsection{Latar Belakang}

\section{PENDAHULUAN}

Dahulu bila kembali melihat ke belakang pada sejarah Indonesia, pada umumnya yang lebih banyak bersekolah adalah laki-laki. Angka partisipasi sekolah untuk anak perempuan selalu lebih rendah daripada anak laki-laki dan jenis pendidikan yang didapatkan oleh anak laki-laki dan perempuan pun berbeda. R.A Kartini adalah seorang pejuang perempuan pertama yang berupaya menegakkan emansipasi perempuan, menginginkan pendidikan formal perempuan sama dengan laki-laki. Namun perjuangan R.A Kartini membutuhkan waktu yang cukup lama untuk terwujud karena hingga tahun 1990 perempuan yang bersekolah (mengenyam pendidikan formal) lebih rendah 75 juta orang daripada laki-laki dan dari jumlah yang buta huruf ternyata dua pertiga adalah perempuan. Rendahnya tingkat pendidikan ini membuat ketimpangan gender semakin tumbuh subur dalam kehidupan masyarakat.

Akhirnya perjuangan yang dilakukan oleh R.A Kartini lama-kelamaan semakin menunjukkan hasilnya. Hal ini terbukti dari Laporan Pencapaian Millenium Development Goals (MDGs) ${ }^{1}$ Indonesia Tahun 2007, Angka Partisipasi Murni (APM) anak perempuan terhadap anak laki-laki pun cenderung meningkat. Jika pada periode sebelumnya (19922002), rasio APM SMA/MA perempuan rata-rata hanya 98,76 persen pertahun maka pada periode 2002-2006 rasio APM meningkat menjadi rata-rata 99,07 persen pertahun. Pada jenjang perguruan tinggi juga mengalami kecenderungan yang sama, rasio APM

${ }^{1}$ Anonim 2008, Voluntary Discrimination dalam Pendidikan Lanjutan dan Tinggi, http://web.g-help.or.id, diakses tanggal 18 Desember 2009. 
perguruan tinggi perempuan meningkat dari rata-rata 85,73 persen (1992-2002) menjadi 97,24 persen (2003-2006). Peningkatan pendidikan ini diharapkan dapat menghapus adanya ketimpangan gender yang berkembang di dalam kehidupan masyarakat.

Walaupun tingkat pendidikan masyarakat baik laki-laki maupun perempuan telah meningkat namun masih menimbulkan suatu pertanyaan besar bahwa hingga saat ini ketimpangan gender tetap tumbuh subur dalam kehidupan masyarakat, contohnya yaitu pada pemilihan jurusan di sekolah lanjutan dan perguruan tinggi. Pemilihan jurusan pada tahun ajaran 2002/2003, siswa perempuan yang bersekolah di SMK program studi Teknologi Industri hanya 1 persen, studi Pertanian dan Kehutanan sekitar 12,9 persen, untuk bidang Bisnis dan Manajemen sebanyak 64,9 persen, dan bidang Pariwisata mencapai 94 persen (UNESCO/LIPI, 2005) $)^{2}$. Ketimpangan gender dapat pula diketahui di kalangan tenaga pengajar dan kepala sekolah. Sudarta (2008) mengungkapkan bahwa walaupun tidak ada data kuantitatif, secara kualitatif kenyataan menunjukkan bahwa untuk Sekolah Taman Kanak-kanak tenaga pengajar didominasi oleh perempuan. Berbeda dengan SD sampai dengan jenjang pendidikan di Perguruan Tinggi, tenaga pengajar laki-laki lebih dominan daripada tenaga pengajar perempuan. Kecenderungan yang serupa juga terlihat di kalangan kepala sekolah dan pimpinan universitas. Hal ini menunjukkan bahwa dari tingkat sekolah dasar hingga perguruan tinggi dimana terdapat orang-orang yang telah berpendidikan tinggi ketimpangan gender masih tetap ada.

Perguruan tinggi merupakan tempat dimana terjadi pendidikan dan latihan akademis yang terkait dengan profesi tertentu (Semiawan, 1999). Perguruan tinggi bertugas membentuk mahasiswanya menjadi kaum intelegensia dan motor penggerak dalam penyebaran ilmu pengetahuan. Mahasiswa adalah seseorang yang sedang dalam proses menimba ilmu ataupun belajar dan terdaftar sedang menjalani pendidikan pada salah satu bentuk perguruan tinggi, yang terdiri dari akademik, politeknik, sekolah tinggi, institut dan universitas (Hartaji, 2009). Melalui mahasiswa diharapkan permasalahan ketimpangan gender yang ada dalam masyarakat dapat berkurang, namun pendidikan yang diterima mahasiswa tidak hanya berasal dari perguruan tinggi tetapi juga berasal dari keluarga yang merupakan tempat pertama pendidikan diterima oleh mahasiswa dan masyarakat yang merupakan tempat mahasiswa melakukan sosialisasi serta bergaul dengan teman-teman sebayanya.

Keluarga adalah pengelompokan kekerabatan yang menyelenggarakan pemeliharaan anak dan kebutuhan manusiawi tertentu (Horton dan Hunt, 1999). Bagi mahasiswa keluarga merupakan suatu kelompok primer yang pertama dan disanalah perkembangan kepribadian bermula. Pendidikan yang diterima oleh mahasiswa dalam keluarga merupakan awal dan pusat bagi seluruh pertumbuhan dan perkembangan mereka untuk menjadi dewasa, dengan demikian menjadi hak dan kewajiban orang tua sebagai penanggung jawab yang utama dalam mendidik mereka. Oleh karena itu tingkat pendidikan orang tua pun akan mempengaruhi cara orang tua dalam memberikan pendidikan kepada mahasiswa.

Selain mendapatkan pendidikan dan berinteraksi dengan orang-orang di dalam lingkungan keluarga, mahasiswa juga akan berinteraksi dan bersosialisasi dengan orangorang yang ada di lingkungan sekolah dan masyarakat. Di lingkungan sekolah mahasiswa akan dipengaruhi oleh guru selaku orang yang memberikan pendidikan dan buku-buku 
pelajaran yang ia dapatkan dan pelajari. Sedangkan di lingkungan masyarakat mahasiswa akan dipengaruhi oleh budaya (sistem kekerabatan dalam keluarga dan masyarakat) dan teman-teman sebayanya (peer group).

Fakta masih adanya ketimpangan gender ini berbeda dengan yang terjadi di STEI TAZKIA yang merupakan sebuah perguruan tinggi dimana mahasiswanya telah mengenyam pendidikan tinggi. Umumnya, walaupun berasal dari keluarga yang ibunya telah mengenyam pendidikan tinggi dan juga telah mengenyam pendidikan tinggi ketimpangan gender masih tetap ada. Berbeda dengan STEI TAZKIA yang ternyata mahasiswanya yang telah berpendidikan tinggi dan berasal dari ibu yang telah mengenyam pendidikan tinggi ternyata persepsi gender mahasiswanya tinggi, sehingga hal ini merupakan hal yang sangat menarik untuk diteliti lebih lanjut. Apakah ketimpangan gender ini dipengaruhi oleh pendidikan yang didapatkan mahasiswa di dalam keluarga atau di dalam lingkungan sekolah tempat ia dididik oleh guru dan lingkungan masyarakat tempat ia berinteraksi dengan budaya dan teman-teman sebayanya (peer group) sehingga mahasiswa masih memiliki persepsi gender yang tinggi. Selain itu juga merupakan suatu hal yang sangat menarik untuk diteliti kemungkinan terdapat perbedaan faktor yang mempengaruhi persepsi gender antara mahasiswa laki-laki dan perempuan.

\subsection{Perumusan Masalah}

Berdasarkan latar belakang di atas, adapun permasalahan yang akan dibahas dalam tulisan ini adalah sebagai berikut :

1. Bagaimanakah pengaruh lingkungan keluarga terhadap persepsi gender mahasiswa?

2. Bagaimanakah pengaruh lingkungan sekolah terhadap persepsi gender mahasiswa?

3. Bagaimanakah pengaruh lingkungan masyarakat terhadap persepsi gender mahasiswa?

4. Apakah perbedaan faktor pengaruh yang terdapat di lingkungan keluarga, sekolah dan masyarakat terhadap persepsi gender mahasiswa?

\subsection{Tujuan}

Berdasarkan perumusan masalah, diperoleh tujuan penulisan sebagai berikut :

1. Menganalisis pengaruh lingkungan keluarga terhadap persepsi gender mahasiswa.

2. Menganalisis pengaruh lingkungan sekolah terhadap persepsi gender mahasiswa.

3. Menganalisis pengaruh lingkungan masyarakat terhadap persepsi gender mahasiswa.

4. Mengetahui perbedaan faktor pengaruh yang terdapat di lingkungan keluarga, sekolah dan masyarakat terhadap persepsi gender mahasiswa.

\subsection{Kegunaan Penulisan}

Penulisan penelitian ini diharapkan dapat memberi manfaat bagi para peneliti yang ingin mengkaji lebih jauh tentang persepsi gender mahasiswa yang berasal dari keluarga yang telah memiliki pendidikan yang tinggi dan pengaruh lingkungan keluarga, sekolah dan masyarakat terhadap persepsi gender mahasiswa.Kalangan praktisi, akademisi dan pemerintah, dapat bermanfaat dalam menambah pengetahuan tentang faktor-faktor yang mempengaruhi persepsi gender mahasiswa.

\section{PENDEKATAN TEORITIS}

\subsection{Tinjauan Pustaka}

\subsubsection{Pendidikan}

Menurut Brown (1961) dalam Ahmadi (2004) pendidikan adalah proses pengendalian secara sadar dimana perubahan-perubahan di dalam tingkah laku dihasilkan 
di dalam diri seseorang melalui kelompok. Sudarta (2008) mengemukakan bahwa pendidikan merupakan proses penerusan nilai oleh pendidik (guru atau dosen) kepada anak didik (siswa atau mahasiswa). Begitu juga dalam Undang-undang Nomor 2 Tahun 1989 tentang Sistem Pendidikan Nasional, disebutkan bahwa: "Pendidikan adalah usaha sadar untuk menyiapkan peserta didik melalui kegiatan bimbingan, pengajaran dan atau latihan bagi penerapannya di masa yang akan datang” (pasal 11 ayat 1). Jadi dapat disimpulkan bahwa pendidikan merupakan suatu proses penerusan nilai secara sadar dari pendidik yang berupa bimbingan, pengajaran, dan atau latihan kepada anak didik yang akan diterapkan di masa yang akan datang sehingga akan terjadi perubahan-perubahan di dalam diri anak didik.

\subsubsection{Gender}

Gender menurut Handayani dan Sugiarti (2008) adalah suatu konsep sosial yang membedakan (dalam arti memilih atau memisahkan) peran antara laki-laki dan perempuan. Menurut Wiliam (2006) gender memuat perbedaan fungsi dan peran sosial laki-laki dan perempuan, yang terbentuk oleh lingkungan. Gender sama sekali berbeda dengan jenis kelamin. Gender bukan jenis kelamin.

Pengetahuan masyarakat tentang gender merupakan suatu hal yang penting untuk dibahas saat ini. Hal ini disebabkan oleh pengetahuan gender masyarakat akan mempengaruhi cara masyarakat memperlakukan orang lain baik itu laki-laki maupun perempuan. Tinggi atau rendahnya pengetahuan masyarakat tentang gender pada umumnya didapat dari hasil pendidikan yang telah dijalani. Pengetahuan masyarakat tentang gender dikatakan tinggi apabila masyarakat tidak lagi membedakan peran dan fungsi antara laki-laki dan perempuan dalam kehidupan bermasyarakat. Begitu juga sebaliknya pengetahuan masyarakat tentang gender dikatakan rendah apabila masyarakat masih membedakan peran dan fungsi antara laki-laki dan perempuan dalam kehidupan bermasyarakat. Persepsi masyarakat tentang gender sangat dipengaruhi oleh pengetahuan masyarakat tentang gender itu sendiri. Persepsi masyarakat tentang gender akan membuat masyarakat mengetahui, memahami, berpendapat dan berprilaku berbeda kepada seseorang, baik ia laki-laki maupun perempuan.

Menurut Baron dan Byrne (2005) persepsi merupakan proses yang digunakan untuk mencoba mengetahui dan memahami perasaan orang lain. Menurut Young (1956) persepsi merupakan aktivitas mengindera, mengintegrasikan dan memberikan penilaian pada obyek-obyek fisik maupun obyek sosial, dan penginderaan tersebut tergantung pada stimulus fisik dan stimulus sosial yang ada di lingkungannya. David (1998) dalam Najah (2007) mengatakan bahwa dengan persepsi, individu dapat menyadari, mengerti tentang keadaan lingkungan di sekitarnya dan juga tentang keadaan diri individu yang bersangkutan. Persepsi juga merupakan pandangan, pengamatan, atau tanggapan seseorang terhadap benda, kejadian, tingkah laku manusia atau hal-hal yang diterimanya sehari-hari.

Persepsi gender adalah proses yang digunakan untuk mencoba mengetahui, memahami dan memberikan penilaian tentang peran antara laki-laki dan perempuan dalam lingkungannya. Mengetahui, memahami dan memberikan penilaian di sini maksudnya adalah suatu proses aktivitas seseorang dalam memberikan kesan, penilaian, pendapat, merasakan dan menginterpretasikan sesuatu berdasarkan informasi yang

3 Young, 1956, Persepsi, www.infoskripsi.com, diakses tanggal 17 April 2010. 
ditampilkan dari sumber lain (yang dipersepsi) ${ }^{4}$ mengenai peran laki-laki dan perempuan dalam lingkungannya.

Persepsi gender di dalam lingkungan keluarga dipengaruhi oleh pendidikan orang tua dan proses pengasuhan yang dilakukan oleh orang tua dalam memberikan pendidikan kepada anaknya terutama ibu. Di dalam bukunya “ The Twelve Who Survive” Myers (1990) dalam Hastuti (2008) menyebutkan bahwa anak dapat tumbuh dan berkembang optimal melalui stimulasi psikososial yang diberikan ibu kepada anak, dan hal ini tergantung pula pada latar belakang pendidikan ibu, beban kerja ibu serta persepsi ibu terhadap peran domestiknya.

Pemberian pendidikan ibu terhadap anaknya terutama pendidikan gender dalam pengasuhan dapat terlihat dari jenis proses pengasuhan yang diberikan oleh ibu. Proses pengasuhan akan melibatkan hubungan dan interaksi yang terjadi antara orang tua dengan anak, keduanya akan terlibat dan berkontribusi dalam membentuk kualitas hubungan dan perkembangan dari hubungan tersebut. Hal ini berarti setiap orang tua akan membawa sejarah bagaimana mereka dahulunya berinteraksi dengan orang tua mereka dahulu dalam membentuk hubungan dengan anak (Rohner (1987) dalam Hastuti (2008)) dan pendidikan yang telah mereka jalani. Selain itu apabila ibu lebih banyak menghabiskan waktunya untuk bekerja maka proses pengasuhan dan pemberian pendidikan kepada anak tidak dapat dilakukan oleh ibu.

\subsubsection{Mahasiswa}

Susantoro (2003) dalam Rahmawati (2006) mengatakan bahwa mahasiswa adalah kalangan muda yang berumur 19-28 tahun yang memang dalam usia tersebut mengalami suatu peralihan dari tahap remaja ke tahap dewasa. Hartaji (2009) mengungkapkan mahasiswa adalah seseorang yang sedang dalam proses menimba ilmu ataupun belajar dan terdaftar sedang menjalani pendidikan pada salah satu bentuk perguruan tinggi, yang terdiri dari akademik, politeknik, sekolah tinggi, institut dan universitas. Susanto (2003) dalam Rahmawati (2006) menyatakan bahwa sosok mahasiswa juga kental dengan nuansa kedinamisan dan sikap keilmuannya dalam melihat sesuatu secara objektif, sistematis, dan rasional.

\subsubsection{Pengasuhan}

Pengasuhan atau disebut juga "parenting” adalah cara mengasuh anak mencakup pengalaman, keahlian, kualitas, dan tanggung jawab yang dilakukan orang tua dalam mendidik dan merawat anak, sehingga anak dapat tumbuh menjadi pribadi yang diharapkan oleh keluarga dan masyarakat di mana ia berada dan tinggal (Hastuti, 2008). Pengasuhan dilakukan tidak hanya untuk memenuhi kebutuhan fisik anak seperti sandang, pangan, dan papan, tetapi pengasuhan juga mencakup pemenuhan kebutuhan psikis anak dan pemberian stimulasi untuk memacu pertumbuhan dan perkembangan anak secara maksimal.

Brooks (2001) dalam Wulandari (2009) mengemukakan bahwa pengasuhan merupakan suatu proses panjang yang mencakup :

1. Interaksi antara anak, orang tua, dan masyarakat lingkungannya.

2. Penyesuaian kebutuhan hidup dan temperamen anak dengan orang tuanya.

3. Pemenuhan tanggung jawab untuk membesarkan anak dan memenuhi kebutuhan anak.

4. Proses mendukung atau menolak keberadaan anak dan orang tua. 
5. Proses mengurangi resiko dan perlindungan terhadap individu dan lingkungan sosialnya.

Kelima proses tersebut sangat menentukan seberapa besar peran orang tua terutama ibu dan pentingnya kebersamaan ibu dalam pengasuhan untuk memberikan pendidikan kepada anaknya agar dapat beradaptasi dan bersosialisasi dengan lingkungannya. Kebersamaan ibu dalam memberikan pengasuhan kepada anaknya akan berdampak pada terbentuknya ikatan (bonding) yang kuat antara ibu dan anaknya dan pemberian pendidikan pun dapat diberikan secara optimal, sebaliknya apabila pengasuhan tidak dilakukan bersama dengan ibu akan berdampak pada lemahnya ikatan antara ibu dan anaknya serta pemberian pendidikan yang terjadi pada saat proses pengasuhan berlangsung tidak dapat diberikan oleh ibu secara optimal.

\subsubsection{Lingkungan}

\subsubsection{Lingkungan Keluarga}

Keluarga adalah unit kesatuan sosial terkecil yang mempunyai peranan sangat penting dalam membina anggota-anggota keluarganya (Rahayu, 2009). Secara prinsip keluarga merupakan unit terkecil dari masyarakat yang terdiri atas dua orang atau lebih berdasarkan pada ikatan perkawinan dan pertalian darah, hidup dalam satu rumah tangga di bawah asuhan seorang kepala rumah tangga, berinteraksi di antara anggota keluarga, setiap anggota keluarga memiliki peranannya masing-masing dalam menciptakan dan mempertahankan budaya keluarga.

Keluarga merupakan lingkungan pertama yang dikenal bagi seseorang begitu ia dilahirkan di dunia. William Bennet dalam Hastuti (2008) mengungkapkan bahwa keluarga adalah tempat yang paling efektif dimana seorang anak menerima kebutuhan kesehatan, pendidikan, dan kesejahteraan bagi hidupnya, serta kondisi kondisi biologis, psikologis, dan pendidikan serta kesejahteraan seorang anak amat tergantung pada keluarga. Jadi untuk menciptakan kesejahteraan bagi anak maka kesejahteraan keluarga merupakan hal utama yang harus dibangun. Apabila anak telah sejahtera, maka akan terbentuk anak yang berkualitas, berkompeten, dan dapat mandiri.

\subsubsection{Lingkungan Sekolah}

Lingkungan sekolah adalah suatu kawasan tempat anak-anak diajarkan untuk mendapatkan, mengembangkan, dan menggunakan sumber-sumber dari keadaan sekitarnya. Sekolah yang merupakan tempat dimana pendidikan diterapkan dan diajarkan untuk memandang sesuatu secara objektif sesuai fakta-fakta yang ada, ternyata terdapat ketimpangan gender. Ada beberapa faktor di lingkungan sekolah yang menyebabkan ketimpangan gender di bidang pendidikan. Menurut Bemmelen (2003 $)$ dalam Sudarta (2008) faktor-faktor ketimpangan gender dalam pendidikan adalah angka buta huruf, Angka Partisipasi Sekolah (APS), pilihan bidang studi, komposisi staf perngajar dan kepala sekolah. Menurut Sudarta (2008) sendiri faktor penentu ketimpangan gender adalah masalah lama (sejarah), nilai gender yang dianut oleh masyarakat, nilai dan peran gender dalam buku ajar, nilai gender yang ditanamkan guru, dan kebijakan yang timpang gender, sehingga dapat disimpulkan bahwa faktor-faktor yang menyebabkan ketimpangan gender adalah :

1. Pilihan Bidang Studi

Ketimpangan gender terlihat juga dalam pilihan bidang studi. Hal ini dapat dibuktikan pada sekolah kejuruan, seperti misalnya Sekolah Kepandaian Puteri (SKP), yakni suatu sekolah khusus untuk anak perempuan, Sekolah Teknik Menengah (STM) 
umumnya untuk anak laki-laki dan sebagainya. Penjurusan di tingkat SLTA, umumnya anak perempuan lebih banyak mengisi jurusan Ilmu Pengetahuan Sosial (IPS), sedangkan anak laki-laki lebih banyak mengisi jurusan Ilmu Pengetahuan Alam (IPA). Berkaitan dengan pilihan fakultas dan jurusan di Perguruan Tinggi yang dinyatakan oleh Sudarta (2008) bahwa proporsi laki-laki dan perempuan di fakultas dan jurusan di Universitas Indonesia (pada tahun 1992/1993) menunjukkan ketimpangan gender yang signifikan. Di samping itu, Agung Ariani (2002) dalam Sudarta (2008) juga menyatakan bahwa umumnya perempuan memilih sekolah yang penyelesaian pendidikannya memerlukan waktu pendek dan cepat bisa bekerja, sebagai alasannya adalah untuk menunjang ekonomi rumah tangga dan untuk biaya melanjutkan studi saudara laki-lakinya.

2. Nilai dan Peran Gender yang Terdapat dalam Buku Ajar

Evaluasi terhadap bahan ajar pada tingkat sekolah dasar misalnya, contoh-contoh seperti ibu pergi ke pasar dan ayah pergi ke kantor sudah harus direvisi. Demikian juga dengan Anti main masak-masakan dan Budi main layangan. Sudarta (2008) juga mengungkapkan contoh mengenai sosialisasi gender di antaranya "Ibu memasak di dapur, Bapak membaca koran”. "Ibu berbelanja ke pasar, Bapak mencangkul di sawah”. Bentuk seksisme lain adalah gambar-gambar yang lebih sering menampilkan anak laki-laki dalam kegiatan yang lebih bervariasi dibandingkan dengan anak perempuan. Selain itu perempuan bisa tidak tampak dalam pelajaran bahasa. Eliyani (2009) mengemukakan contoh lain ketimpangan gender dalam buku ajar yaitu bentuk nominal bermakna profesi seperti peneliti, pilot, pengusaha dan presiden dianggap mengandung makna laki-laki, karena apabila penyandang profesi tersebut adalah perempuan, kata-kata itu biasanya dimaknai dengan kata perempuan agar sosok perempuan termunculkan dalam kata-kata tersebut.

3. Nilai Gender yang Ditanamkan Oleh Guru

Guru merupakan "role model" yang sangat penting di luar lingkungan keluarga anak. Disadari atau tidak, setiap orang termasuk guru mempunyai persepsi tentang peran gender yang pantas. Persepsi itu akan disampaikan secara langsung atau tidak langsung kepada murid (Bemmelen (2003 $)$ dalam Sudarta (2008)). Guru taman kanak-kanak dan sekolah dasar lebih memberikan penguatan positif pada anak perempuan dibanding dengan anak laki-laki dalam memberi instruksi dan aktivitas bermain. Memasuki sekolah menengah pertama dan menengah atas, baik oleh guru di sekolah dan orang tua di rumah, menasehati agar remaja laki-laki tidak cengeng dan remaja perempuan harus bisa memasak. Selain itu hasil penelitian, dalam dunia sains yang dipaparkan oleh Eliyani (2009) umumnya juga menunjukkan bahwa tenaga pengajar memiliki persepsi yang sama dengan masyarakat luas, yaitu sains dan teknologi adalah dunia laki-laki. Sikap ini membuat mereka merasa wajar bila dalam kelas terdapat hanya sedikit anak perempuan. Lebih jauh tenaga pengajar juga cenderung lebih memberikan perhatian pada pelajar lakilaki daripada pelajar perempuan terutama pada bidang-bidang yang "dominan laki-laki” (Voyless et al (2007) dalam Eliyani (2009)), seperti lebih banyak memanggil anak lakilaki, memberikan penghargaan dan kritik lebih banyak pada anak laki-laki atau di laboratorium memberikan ekspektasi lebih pada anak laki-laki daripada anak perempuan.

\subsubsection{Lingkungan Masyarakat}

Masyarakat adalah sekelompok manusia yang secara relatif mandiri, hidup bersama-sama dalam waktu yang cukup lama, mendiami suatu tertentu, memiliki kebudayaan yang sama, dan melakukan sebagian besar kegiatannya dalam kelompok 
tersebut (Horton dan Hunt, 1999). Jadi lingkungan masyarakat adalah suatu kawasan tempat sekelompok manusia yang secara relatif mandiri, hidup bersama-sama, memiliki kebudayaan yang sama, dan melakukan sebagian besar kegiatannya dalam kelompok tersebut.

Salah satu penyebab ketimpangan gender di dalam lingkungan masyarakat adalah budaya. Banyak yang menganggap bahwa kondisi demikian normal saja. Seumur hidup, telah melihat suatu fakta bahwa perempuan bekerja di sektor domestik dan laki-laki mencari nafkah. Anak perempuan main boneka dan anak laki-laki main mobil-mobilan. Budaya yang demikian bukan hanya diterima baik oleh laki-laki tetapi juga perempuan.

Di Indonesia pada dasarnya terdapat suatu budaya kekeluargaan atau kekerabatan yang mengatur kehidupan masyarakatnya, terdiri dari tiga sistem kekerabatan yaitu :

1. Sistem kekerabatan patrilinial yaitu sistem kekerabatan yang menarik garis keturunan dari garis laki-laki (ayah), sistem ini dianut di Tapanuli, Lampung, Bali dan lain-lain.

2. Sistem kekerabatan matrilinial yaitu sistem kekerabatan yang menarik garis keturunan dari garis perempuan (ibu), sistem ini banyak dianut oleh masyarakat Sumatra Barat.

3. Sistem kekerabatan parental yaitu sistem kekerabatan yang menarik garis keturunan dari garis laki-laki (ayah) dan perempuan (ibu), sistem ini banyak dianut oleh masyarakat Jawa, Madura, Sumatra Selatan dan lain-lainnya

Menurut Purba (2005) ketimpangan gender selalu dihubungkan dengan perspektif ideologi patrilinial dan sosialisasi nilai dalam kehidupan rumah tangga. Akibatnya ideologi patrilinial tersebut tetap dapat mempertahankan ketimpangan gender dalam kehidupan masyarakat. Selain patrilinial, ideolagi matrilinial juga menyebabkan ketimpangan gender karena ideologi ini lebih mengutamakan perempuan dibandingkan laki-laki.

Sudarta (2008) mengungkapkan bahwa ada dua nilai gender yang menonjol yang masih berlaku di masyarakat, terutama di masyarakat pedesaan yaitu pendapat masyarakat yang mengatakan "Untuk apa anak perempuan disekolahkan (tinggi-tinggi), nanti dia ke dapur juga" dan "Untuk apa perempuan disekolahkan (tinggi-tinggi), nanti dia akan menjadi milik orang lain juga”. Pada masyarakat yang menganut sistem kekerabatan patrilinial, nilai gender tersebut tampak lebih menonjol seperti masyarakat yang cenderung lebih mengutamakan anak laki-laki daripada anak perempuan di dalam memberikan kesempatan untuk mengikuti pendidikan formal. Tidak berbeda dengan patrilinial, dalam sistem matrilinial perempuan merupakan ujung tombak untuk meneruskan garis keturunan keluarga dan sebagian besar hak waris diberikan kepada perempuan.

Selain budaya di dalam lingkungan masyarakat, anak juga akan dipengaruhi oleh teman sebayanya (peer group). Menurut Horton dan Hunt (1999) peer group adalah suatu kelompok dari orang-orang yang seusia dan memiliki status yang sama, dengan siapa seseorang umumnya berhubungan atau bergaul. Di mulai dari masa anak-anak hingga dewasa sebagian besar orang akan membangun pertemanan dengan teman sebaya yang memiliki minat yang sama. Secara umum, Hartup dan Stevens (1999) dalam Baron dan Byrne (2005) mengatakan bahwa memiliki teman adalah suatu hal yang positif sebab teman dapat mendorong self-esteem dan menolong dalam mengatasi stress, tetapi teman juga dapat memiliki efek negatif jika mereka antisosial, menarik diri, tidak suportif, argumentatif, atau tidak stabil. 
Peer group merupakan suatu wadah untuk bersosialisasi. Menurut Havighurst dalam Ahmadi (2004) peer group memiliki tiga fungsi, yaitu :

a. Mengajarkan kebudayaan

b. Mengajarkan mobilitas sosial atau perubahan status.

c. Memberi peranan sosial yang baru.

Jadi di dalam peer group anak akan belajar banyak hal diantaranya adalah budaya, status dan peranannya baik dalam kehidupan keluarga, sekolah maupun masyarakat.

\subsection{Kerangka Pemikiran}

Pendidikan adalah usaha sadar untuk menyiapkan peserta didik melalui kegiatan bimbingan, pengajaran dan atau latihan bagi penerapannya di masa yang akan datang. Pengasuhan atau disebut juga "parenting" adalah cara mengasuh anak mencakup pengalaman, keahlian, kualitas, dan tanggung jawab yang dilakukan orang tua dalam mendidik dan merawat anak, sehingga anak dapat tumbuh menjadi pribadi yang diharapkan oleh keluarga dan masyarakat di mana ia berada dan tinggal (Hastuti, 2008).

Menurut banyak ahli jiwa, fase anak menjadi seorang remaja akhir berkisar pada umur 17-19 tahun atau 17-21 tahun (Kartono (1990) dalam Wulandari (2009)). Mahasiswa digolongkan ke dalam fase remaja akhir dan memasuki fase dewasa awal karena mahasiswa terdiri dari sekelompok pemuda dan pemudi yang yang berkisar pada umur 18-30 tahun dengan mayoritas kelompok umur sekitar 18-25 tahun (Ahmad dan Sholeh (2006) dalam Wulandari (2009)). Mahasiswa adalah seseorang yang sedang dalam proses menimba ilmu ataupun belajar dan terdaftar sedang menjalani pendidikan pada salah satu bentuk perguruan tinggi, yang terdiri dari akademik, politeknik, sekolah tinggi, institut dan universitas (Hartaji, 2009). Mahasiswa mendapatkan pendidikan bukan hanya di lingkungan sekolah (perguruan tinggi) tetapi mahasiswa juga mendapatkan pendidikan dari lingkungan keluarga semenjak ia masih kecil dan lingkungan masyarakat.

Persepsi gender adalah proses yang digunakan untuk mencoba mengetahui memahami perasaan orang lain dan memberikan penilaian tentang peran antara laki-laki dan perempuan dalam lingkungannya. Mengetahui, memahami dan memberikan penilaian di sini maksudnya adalah suatu proses aktivitas seseorang dalam memberikan kesan, penilaian, pendapat, merasakan dan menginterpretasikan sesuatu berdasarkan informasi yang ditampilkan dari sumber lain (yang dipersepsi) mengenai peran laki-laki dan perempuan dalam lingkungannya. Di lingkungan keluarga persepsi gender mahasiswa dipengaruhi oleh pendidikan ibu dan pengasuhan yang mahasiswa terima dari ibu mereka. Semakin tinggi tingkat pendidikan ibu maka pengetahuan ibu tentang gender semakin luas. Luasnya pengetahuan ibu tentang gender akan berdampak pada pendidikan yang ibu berikan pada mahasiswa ketika proses pengasuhan berlangsung yang merupakan pendidikan yang bermuatan gender.

Pendidikan yang ibu berikan kepada mahasiswa pada waktu kecil sangat bergantung pada pengasuhan yang dilakukan ketika mahasiswa bersama dengan ibu atau pengasuhan tersebut dilakukan oleh ibu sendiri. Adanya kebersamaan mahasiswa dengan ibu ketika proses pengasuhan berlangsung maka pendidikan gender yang diberikan oleh ibu dapat tersampaikan dan sebaliknya apabila proses pengasuhan berlangsung tanpa kebersamaan dengan ibu maka pendidikan gender yang seharusnya diberikan oleh ibu pada akhirnya tidak tersampaikan.

Selain pendidikan ibu dan pengasuhan ibu di dalam lingkungan keluarga, lingkungan sekolah dan lingkungan masyarakat juga dapat mempengaruhi persepsi 
gender mahasiswa. Lingkungan sekolah merupakan tempat mahasiswa diajarkan untuk mendapatkan, mengembangkan, dan menggunakan sumber-sumber dari keadaan sekitarnya. Lingkungan sekolah akan mempengaruhi mahasiswa dari pengajaran tentang pilihan bidang studi, nilai dan peran gender yang ada dalam buku ajar dan yang ditanamkan oleh guru sebagai role model di sekolah. Lingkungan masyarakat merupakan tempat mahasiswa bersosialisasi dengan budaya masyarakat dan teman-teman sebayanya. Di dalam lingkungan masyarakat budaya dan peer group-lah yang cukup kuat untuk mempengaruhi persepsi gender mahasiswa karena mahasiswa setiap hari akan berinteraksi dengan budaya dan teman-temannya.

Alur Kerangka Pemikiran

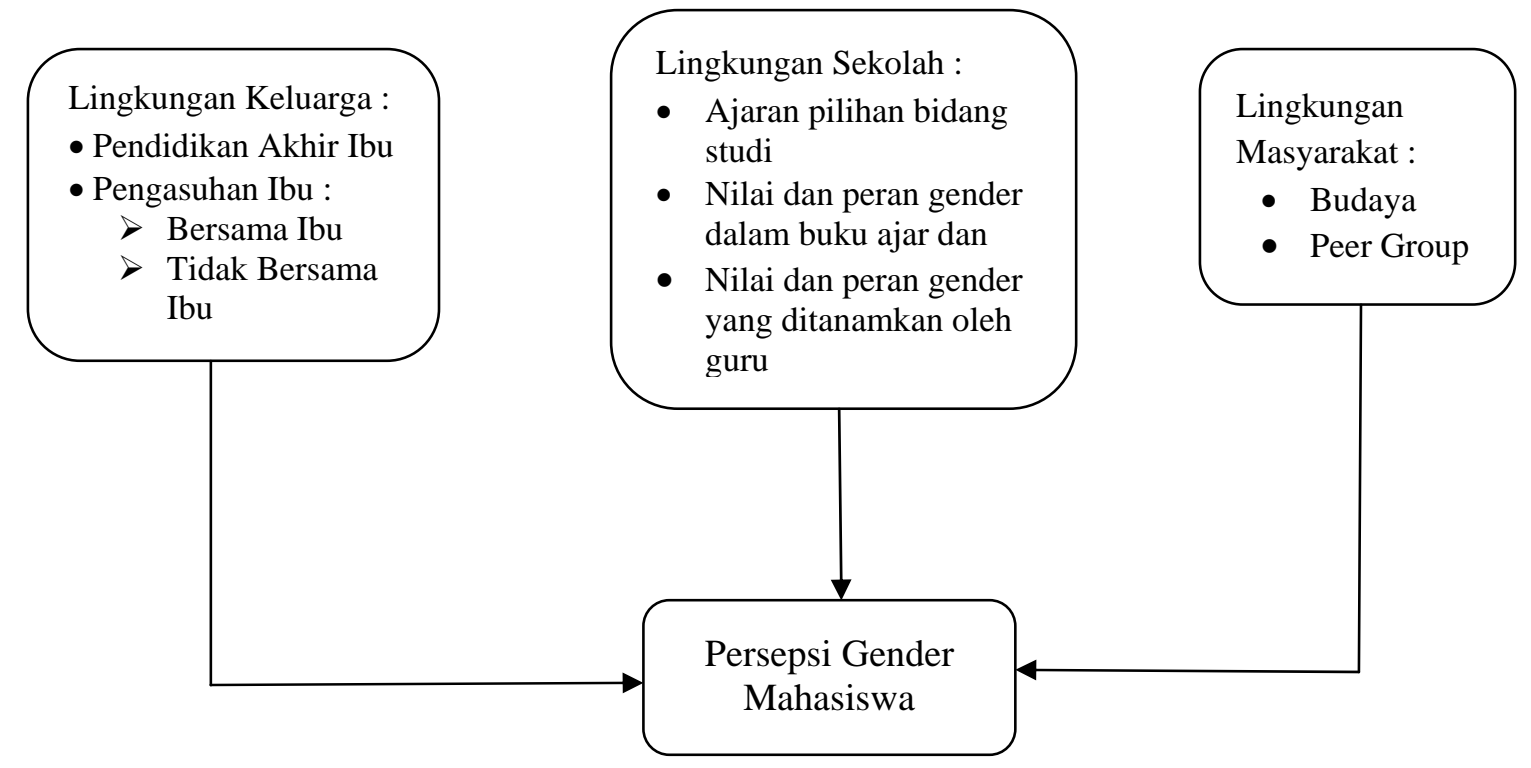

Gambar 1. Kerangka pemikiran

Keterangan :

$\longrightarrow$ : Pengaruh langsung

\subsection{Hipotesis Pengarah}

Hipotesis adalah jawaban sementara dari persoalan yang diteliti (Sarwono, 2006). Berdasarkan tinjauan pustaka dan kerangka pemikiran maka hipotesis yang didapat adalah :

1. Diduga bahwa terdapat hubungan antara lingkungan keluarga dengan persepsi gender mahasiswa. Semakin banyak pendidikan gender yang diterima mahasiswa dari lingkungan keluarga maka semakin tinggi persepsi gender mahasiswa.

2. Diduga bahwa terdapat hubungan antara lingkungan sekolah dengan persepsi gender mahasiswa. Semakin banyak pendidikan gender yang mengajarkan keseimbangan kedudukan antara laki-laki dan perempuan yang diterima mahasiswa dari lingkungan sekolah maka semakin tinggi persepsi gender mahasiswa.

3. Diduga bahwa terdapat hubungan antara lingkungan masyarakat dengan persepsi gender mahasiswa. Semakin banyak pendidikan gender yang mengajarkan keseimbangan 
kedudukan antara laki-laki dan perempuan yang diterima mahasiswa dari lingkungan masyarakat maka semakin tinggi persepsi gender mahasiswa.

4. Diduga bahwa terdapat perbedaan faktor yang mempengaruhi persepsi gender mahasiswa laki-laki dan perempuan baik di lingkungan keluarga, sekolah dan masyarakat.

\subsection{Metode Penelitian}

\section{PENDEKATAN LAPANGAN}

Penelitian ini menggunakan kombinasi pendekatan kuantitatif yang dilakukan dengan menggunakan metode survei dan pendekatan kualitatif yang dilakukan dengan wawancara dan observasi lokasi penelitian. Data yang digunakan dalam penelitian berupa data primer yang dapat diperoleh melalui pengisian kuisioner dan wawancara mendalam dan data sekunder dapat diperoleh melalui dokumen-dokumen dari (lokasi penelitian) dan sumber pustaka lain yang bisa didapat dari buku, artikel, skripsi, tesis dan jurnal yang berkaitan dengan topik penelitian.

\subsection{Lokasi dan Waktu Penelitian}

Penelitian ini akan dilaksanakan di STEI TAZKIA, Kelurahan Margajaya, Kecamatan Bogor Barat, Jawa Barat. Lokasi penelitian dipilih karena pada umumnya fenomena ketimpangan gender masih tetap ada di tengah-tengah masyarakat yang telah berpendidikan tinggi dan berasal dari keluarga (ibu) yang telah mengenyam pendidikan tinggi terutama bagi mahasiswa, namun hal ini berbeda dengan mahasiswa yang ada di STEI TAZKIA dan berasal dari keluarga yang telah mengenyam pendidikan tinggi ternyata memiliki persepsi gender yang tinggi. Fenomena ini berbeda dari fenomena yang biasa terjadi pada umumnya sehingga merupakan suatu hal yang sangat menarik untuk diteliti lebih lanjut. Penelitian telah dilaksanakan pada awal April dan berakhir pada Mei 2010 .

\subsection{Teknik Penentuan Responden dan Informan}

Penentuan responden dalam penelitian ini adalah dengan mengambil seluruh populasi. Hal ini disebabkan oleh jumlah populasi yang ada hanya 30 orang sehingga peneliti akan mempergunakan populasi mahasiswa sebagai responden dalam penelitian ini. Awalnya mahasiswa yang memenuhi syarat untuk menjadi responden berjumlah 33 orang namun 3 orang menolak untuk menjadi responden sehingga total mahasiswa yang bersedia menjadi responden berjumlah 30 orang. Populasi ini diambil berdasarkan angket yang telah disebarkan terlebih dahulu, dari 230 mahasiswa didapat hanya 30 orang yang bersedia dan memenuhi syarat untuk menjadi responden. Syarat yang harus dipenuhi untuk menjadi responden yaitu responden harus memiliki seorang ibu yang bekerja, responden pernah diasuh oleh orang lain selain ibu (pengasuh) dan minimal pendidikan akhir ibu adalah tingkat SLTA. Informan dalam penelitian ini adalah mahasiswa sendiri dan beberapa orang staf STIE TAZKIA. Adanya informan ini berfungsi untuk menambah informasi yang dibutuhkan terkait dengan penelitian ini dan pemilihan informan dipilih dengan menggunakan teknik pusposive sampling atau secara sengaja.

\subsection{Teknik Pengolahan dan Analisis Data}

Data kuantitatif yang akan didapatkan dari hasil penelitian akan diolah ke dalam program Microsoft Excel 2007 dan SPSS 16,0. Uji statistik yang digunakan adalah tabulasi frekuensi, tabulasi silang dan Spearman. Hal ini ditujukan untuk melihat adanya hubungan antara variabel pengaruh dan variabel terpengaruh serta korelasi antara 
keduanya. Pengukuran analisis data kualitatif hanya terbatas pada teknik pengolahan data seperti membaca tabel atau diagram yang kemudian dianalisis secara kualitatif.

\section{GAMBARAN UMUM LOKASI PENELITIAN}

\subsection{Gambaran Umum Lokasi Penelitian}

\subsubsection{Gambaran Umum STEI TAZKIA}

Sekolah Tinggi Ekonomi Islam TAZKIA (STEI TAZKIA) yang beralamat di Jalan Raya Darmaga KM 7 Bogor, merupakan perguruan tinggi yang lahir dalam krisis ekonomi tahun 1997 - 1998. Setelah menyelenggarakan berbagai pelatihan tentang perbankan syariah bagi para bankir dan pejabat di lingkungan Bank Indonesia serta terlibat dalam proses konsultasi dalam konversi bank umum menjadi bank syariah, Tazkia termotivasi untuk mendirikan lembaga pendidikan guna menghasilkan sumberdaya insani yang kompeten untuk mengembangkan perbankan syariah pada khususnya dan ekonomi syariah pada umumnya. Upaya ini diwujudkan dalam bentuk pendirian Sekolah Tinggi Ekonomi Islam TAZKIA (STEI TAZKIA) melalui pendirian Yayasan Tazkia Cendekia pada pertengahan tahun 1999.

Setiap tahunnya jumlah mahasiswa yang diterima di STEI TAZKIA berbeda-beda, salah satunya yaitu mahasiswa yang diterima di tahun 2009 (angkatan 2009). Jumlah mahasiswa angkatan 2009 yaitu sebanyak 230 orang. Berdasarkan Tabel 1 dapat diketahui bahwa jumlah seluruh mahasiswa STEI TAZKIA angkatan 2009 terdiri dari perempuan yang berjumlah 129 orang (56,1\%) dan laki-laki berjumlaj 101 orang (43,9\%).

Tabel 1. Jumlah dan Persentase Mahasiswa STEI TAZKIA Angkatan 2009

Berdasarkan Jenis Kelamin, Bogor 2010

\begin{tabular}{|l|c|c|}
\hline \multicolumn{1}{|c|}{ Jenis Kelamin } & Jumlah (n) & Persentase (\%) \\
\hline Perempuan & 129 & 56,1 \\
\hline Laki-Laki & 101 & 43,9 \\
\hline Total & 230 & 100,0 \\
\hline
\end{tabular}

Berdasarkan Tabel 2 untuk mahasiswa yang berusia 17 tahun sebanyak 16 orang (7,0\%), berusia 18 tahun 129 orang (56,1\%), berusia 19 tahun sebanyak 51 orang (22,2\%), berusia 20 tahun sebanyak 8 orang (3,5\%), berusia 21 tahun sebanyak 20 orang $(8,7 \%)$, berusia 22 tahun sebanyak 4 orang (1,7\%), dan berusia 23 tahun sebanyak 1 orang $(0,4 \%)$.

Tabel 2. Jumlah dan Persentase Mahasiswa STEI TAZKIA Angkatan 2009 Berdasarkan Umur, Bogor 2010

\begin{tabular}{|c|c|c|}
\hline Usia & Jumlah (n) & Persentase (\%) \\
\hline 17 & 16 & 7,0 \\
\hline 18 & 129 & 56,1 \\
\hline 19 & 51 & 22,2 \\
\hline 20 & 8 & 3,5 \\
\hline 21 & 20 & 8,7 \\
\hline 22 & 4 & 1,7 \\
\hline 23 & 1 & 0,4 \\
\hline Total & 230 & 100,0 \\
\hline
\end{tabular}


Tabel 3 menunjukkan mahasiswa yang berasal dari daerah Sunda sebanyak 121 orang (52,6\%), daerah Sumatra sebanyak 32 orang (13,9\%), daerah Nusa Tenggara sebanyak 28 orang (12,2\%), daerah Jawa sebanyak 21 orang (9,1\%), daerah Jakarta sebanyak 19 orang (8,3\%), daerah Kalimantan sebanyak 5 orang (2,2\%), dan dari daerah Sulawesi sebanyak 4 orang (1,7\%).

Tabel 3. Jumlah dan Persentase Mahasiswa STEI TAZKIA Angkatan 2009

Berdasarkan Asal Daerah, Bogor 2010

\begin{tabular}{|l|c|c|}
\hline \multicolumn{1}{|c|}{ Asal Daerah } & Jumlah (n) & Persentase (\%) \\
\hline Sunda & 121 & 52,6 \\
\hline Sumatra & 32 & 13,9 \\
\hline Nusa Tenggara & 28 & 12,2 \\
\hline Jawa & 21 & 9,1 \\
\hline Jakarta & 19 & 8,3 \\
\hline Kalimantan & 5 & 2,2 \\
\hline Sulawesi & 4 & 1,7 \\
\hline Total & 230 & 100,0 \\
\hline
\end{tabular}

Banyak anggapan yang menyatakan bahwa pada umumnya mahasiswa yang diterima di STEI TAZKIA adalah mahasiswa yang dulunya sekolah bersekolah di pesantren, namun pada kenyataannya ternyata STEI TAZKIA menerima mahasiswa yang berasal dari sekolah manapun. Tabel 4 menunjukkan bahwa STEI TAZKIA menerima mahasiswa yang berasal dari SMA sebanyak 96 orang (41,7\%), MA sebanyak 71 orang (30,9\%), Pesantren sebanyak 32 orang (13,9\%), dan SMA IT (Islam Terpadu) sebanyak 31 orang $(13,5 \%)$.

Tabel 4. Jumlah dan Persentase Mahasiswa STEI TAZKIA Angkatan 2009 Berdasarkan Asal Sekolah, Bogor 2010

\begin{tabular}{|l|c|c|}
\hline \multicolumn{1}{|c|}{ Asal Sekolah } & Jumlah (n) & Persentase (\%) \\
\hline SMA & 96 & 41,7 \\
\hline MA Boarding School & 71 & 30,9 \\
\hline Pesantren & 32 & 13,9 \\
\hline SMA IT Boarding School & 31 & 13,5 \\
\hline Total & 230 & 100,0 \\
\hline
\end{tabular}

Tabel 5 yang menunjukkan tingkat pendidikan ibu, ibu yang berpendidikan SD sebanyak 22 orang (9,6\%), SMP sebanyak 29 orang (12,6\%), SMA sebanyak 91 orang (39,6\%), Diploma 37 orang (16,1\%), S1 sebanyak 48 orang (20,9\%) dan S2 sebanyak 3 orang $(1,3 \%)$.

Tabel 5. Jumlah dan Persentase Mahasiswa STEI TAZKIA Angkatan 2009 Berdasarkan Pendidikan Ibu, Bogor 2010

\begin{tabular}{|l|c|c|}
\hline \multicolumn{1}{|c|}{ Pendidikan Ibu } & Jumlah (n) & Persentase (\%) \\
\hline SD & 22 & 9,6 \\
\hline SMP & 29 & 12,6 \\
\hline SMA & 91 & 39,6 \\
\hline Diploma & 37 & 16,1 \\
\hline S1 & 48 & 20,9 \\
\hline S2 & 3 & 1,3 \\
\hline Total & 230 & 100,0 \\
\hline
\end{tabular}




\subsection{Karakteristik Umum Mahasiswa}

Responden dalam penelitian ini adalah mahasiswa yang berjumlah 30 orang dan merupakan mahasiswa STEI TAZKIA angkatan 2009. Karakteristik umum mahasiswa dibedakan menjadi beberapa karakteristik guna untuk memperjelas karakter dari mahasiswa yang menjadi mahasiswa dalam penelitian ini.

\subsubsection{Karakteristik Mahasiswa Berdasarkan Jenis Kelamin}

Sebagian besar mahasiswa yang menjadi mahasiswa dalam penelitian ini adalah berjenis kelamin perempuan. Mahasiswa yang berjenis kelamin perempuan sebanyak 16 orang (53,3\%) dan yang berjenis kelamin laki-laki sebanyak 14 orang (46,7\%).

Tabel 6. Jumlah dan Persentase Mahasiswa Berdasarkan Jenis Kelamin, Bogor 2010

\begin{tabular}{|l|c|c|}
\hline \multicolumn{1}{|c|}{ Jenis Kelamin } & Jumlah (n) & Persentase (\%) \\
\hline Perempuan & 16 & 53,3 \\
\hline Laki-Laki & 14 & 46,7 \\
\hline Total & 30 & 100,0 \\
\hline
\end{tabular}

\subsubsection{Karakteristik Mahasiswa Berdasarkan Usia}

Tabel 7 menunjukkan bahwa sebagian besar mahasiswa berusia 18 tahun. Mahasiswa yang berusia 18 tahun berjumlah 13 orang (43,3\%), berusia 19 tahun berjumlah 12 orang (40,0\%), berusia 20 tahun berjumlah 3 orang (10\%), berusia 21 tahun berjumlah 1 orang (3,3\%) dan berusia 22 tahun berjumlah 1 orang (3,3\%).

Tabel 7. Jumlah dan Persentase Mahasiswa Berdasarkan Usia, Bogor 2010

\begin{tabular}{|c|c|c|}
\hline Usia & Jumlah (n) & Persentase (\%) \\
\hline 18 & 13 & 43,3 \\
\hline 19 & 12 & 40,0 \\
\hline 20 & 3 & 10,0 \\
\hline 21 & 1 & 3,3 \\
\hline 22 & 1 & 3,3 \\
\hline Total & 30 & 100,0 \\
\hline
\end{tabular}

\subsubsection{Karakteristik Mahasiswa Berdasarkan Asal Daerah}

Sebagian besar mahasiswa berasal dari daerah Jawa dan Sumatra. Mahasiswa yang berasal dari Sumatra berjumlah 8 orang (26,7\%), Jawa 8 orang (26,7\%), Sunda 7 orang (23,3\%), Nusa Tenggara 3 orang (10,0\%), Jakarta 2 orang (6,7\%), Sulawesi 1 orang (3,3\%), dan Kalimantan 1 orang (3,3\%).

Tabel 8. Jumlah dan Persentase Mahasiswa Berdasarkan Asal Daerah, Bogor 2010

\begin{tabular}{|l|c|c|}
\hline \multicolumn{1}{|c|}{ Asal Daerah } & Jumlah (n) & Persentase (\%) \\
\hline Sumatra & 8 & 26,7 \\
\hline Jawa & 8 & 26,7 \\
\hline Sunda & 7 & 23,3 \\
\hline Nusa Tenggara & 3 & 10,0 \\
\hline Jakarta & 2 & 6,7 \\
\hline Sulawesi & 1 & 3,3 \\
\hline Kalimantan & 1 & 3,3 \\
\hline Total & 30 & 100,0 \\
\hline
\end{tabular}




\subsubsection{Karakteristik Mahasiswa Berdasarkan Asal Sekolah}

Setiap mahasiswa berasal dari sekolah yang berbeda-beda sebelum mereka bersekolah di STIE TAZKIA. Sebagian besar mahasiswa bersekolah di SMA yaitu sebanyak 13 orang (43,3\%), selain itu ada juga yang bersekolah di MA Boarding School sebanyak 8 orang (26,7\%), Pesantren sebanyak 5 orang $(16,7 \%)$ dan SMA IT (Islam Terpadu) Boarding School sebanyak 4 orang (13,3\%).

Mahasiswa yang bersekolah di SMA tidak tinggal di asrama sedangkan yang bersekolah di MA Boarding School pada umumnya tinggal di asrama tetapi ada juga yang tidak tinggal di asrama dan mahasiswa yang bersekolah di pesantren serta SMA IT Boarding School mereka diharuskan untuk tinggal di asrama. Dampaknya adalah bagi mahasiswa yang bersekolah di pesantren, SMA IT Boarding School, dan sebagian di MA Boarding School mereka tidak bisa bertemu dengan keluarga mereka terutama ibu mereka sehingga mereka lebih banyak menerima pengasuhan dari guru mereka di sekolah dibandingkan dengan ibu mereka sendiri. Bagi mahasiswa yang bersekolah di SMA, dan sebagian MA Boarding School dapat tinggal dengan orang tua mereka namun mereka tetap memiliki waktu yang sedikit untuk bertemu dengan ibu mereka karena banyaknya kegiatan yang mereka ikuti di sekolah sehingga waktu mereka lebih banyak di sekolah daripada di rumah.

Tabel 9. Jumlah dan Persentase Mahasiswa Berdasarkan Asal Sekolah, Bogor 2010

\begin{tabular}{|l|c|c|}
\hline \multicolumn{1}{|c|}{ Asal Sekolah } & Jumlah (n) & Persentase (\%) \\
\hline SMA & 13 & 43,3 \\
\hline MA Boarding School & 8 & 26,7 \\
\hline Pesantren & 5 & 16,7 \\
\hline SMA IT Boarding School & 4 & 13,3 \\
\hline Total & 30 & 100,0 \\
\hline
\end{tabular}

\subsubsection{Karakteristik Mahasiswa Berdasarkan Pendidikan Akhir Ibu}

Tingkat pendidikan ibu mahasiswa berbeda-beda. Pendidikan orang tua mahasiswa digolongkan menjadi tiga golongan, yaitu mahasiswa yang ibunya berpendidikan S1 (tinggi) sebanyak 14 orang (46,7\%), Diploma (sedang) 6 orang (20\%), dan SLTA (rendah) 10 orang (33,3\%). Jadi pada umumnya ibu mahasiswa telah mengenyam pendidikan tinggi yaitu S1.

Tabel 10. Jumlah dan Persentase Mahasiswa Berdasarkan Pendidikan Akhir Ibu, Bogor 2010

\begin{tabular}{|c|c|c|c|c|c|c|}
\hline \multirow{2}{*}{ Pendidikan Ibu } & \multicolumn{4}{|c|}{ Jenis Kelamin } & \multicolumn{2}{|c|}{ Total } \\
\cline { 2 - 5 } & Laki-laki & \multicolumn{2}{|c|}{ Perempuan } & \multicolumn{2}{|c|}{} \\
\cline { 2 - 5 } & $\mathrm{n}$ & $\%$ & $\mathrm{n}$ & $\%$ & $\mathrm{n}$ & $\%$ \\
\hline S1 & 7 & 23,3 & 7 & 23,3 & 14 & 46,7 \\
\hline Diploma & 2 & 6,7 & 4 & 13,3 & 6 & 20,0 \\
\hline SLTA & 5 & 16,7 & 5 & 16,7 & 10 & 33,3 \\
\hline Total & 14 & 46,7 & 16 & 53,3 & 30 & 100,0 \\
\hline
\end{tabular}

\subsubsection{Karakteristik Mahasiswa Berdasarkan Pekerjaan Ibu}

Orang tua mahasiswa khususnya ibu mahasiswa memiliki jenis pekerjaan yang berbeda-beda, tetapi pekerjaan yang paling dominan yang digeluti oleh ibu mahasiswa adalah guru yaitu sebanyak 9 orang (30,0\%) kemudian diikuti oleh PNS (Pegawai Negeri 
Sipil) sebanyak 8 orang (26,7\%), wiraswasta 6 orang (20,0\%), wirausaha 6 orang $(20,0 \%)$ dan petani 1 orang $(3,3 \%)$.

Tabel 11. Jumlah dan Persentase Mahasiswa Berdasarkan Pekerjaan Ibu, Bogor 2010

\begin{tabular}{|l|c|c|c|c|c|c|}
\hline \multirow{3}{*}{ Pekerjaan Ibu } & \multicolumn{4}{|c|}{ Jenis Kelamin } & \multicolumn{2}{c|}{ Total } \\
\cline { 2 - 7 } & \multicolumn{2}{|c|}{ Laki-laki } & \multicolumn{2}{c|}{ Perempuan } & \multicolumn{2}{c|}{} \\
\cline { 2 - 7 } & $\mathrm{n}$ & $\%$ & $\mathrm{n}$ & $\%$ & $\mathrm{n}$ & $\%$ \\
\hline Guru & 4 & 13,3 & 5 & 16,7 & 9 & 30,0 \\
\hline PNS & 4 & 13,3 & 4 & 13,3 & 8 & 26,7 \\
\hline Wiraswasta & 1 & 3,3 & 5 & 16,7 & 6 & 20,0 \\
\hline Wirausaha & 4 & 13,3 & 2 & 6,7 & 6 & 20,0 \\
\hline Petani & 1 & 3,3 & 0 & 0 & 1 & 3,3 \\
\hline Total & 14 & 46,7 & 16 & 53,3 & 30 & 100,0 \\
\hline
\end{tabular}

\subsubsection{Karaktristik Mahasiswa Berdasarkan Asal Daerah Ibu}

Tabel 12 menunjukkan bahwa ibu mahasiswa yang berasal dari daerah Jawa sebanyak 12 orang $(40,0 \%)$, Sumatra 9 orang (30,0\%), Sunda 4 orang (13,3\%), Kalimantan 2 orang (6,7\%), Sulawesi 1 orang (3,3\%), Jakarta 1 orang (3,3\%), dan Nusa Tenggara 1 orang $(3,3 \%)$.

Tabel 12. Jumlah dan Persentase Mahasiswa Berdasarkan Asal Daerah Ibu, Bogor 2010

\begin{tabular}{|l|c|c|c|c|c|c|}
\hline \multirow{3}{*}{ Suku Bangsa Ibu } & \multicolumn{4}{|c|}{ Jenis Kelamin } & \multicolumn{2}{c|}{ Total } \\
\cline { 2 - 5 } & \multicolumn{2}{|c|}{ Laki-laki } & \multicolumn{2}{c|}{ Perempuan } & \multicolumn{2}{c|}{} \\
\cline { 2 - 5 } & $\mathrm{n}$ & $\%$ & $\mathrm{n}$ & $\%$ & $\mathrm{n}$ & $\%$ \\
\hline Jawa & 6 & 20,0 & 6 & 20,0 & 12 & 40,0 \\
\hline Sumatra & 5 & 16,7 & 4 & 13,3 & 9 & 30,0 \\
\hline Sunda & 2 & 6,7 & 2 & 6,7 & 4 & 13,3 \\
\hline Kalimantan & 0 & 0 & 2 & 6,7 & 2 & 6,7 \\
\hline Jakarta & 1 & 3,3 & 0 & 0 & 1 & 3,3 \\
\hline Nusa Tenggara & 0 & 0 & 1 & 3,3 & 1 & 3,3 \\
\hline Sulawesi & 0 & 0 & 1 & 3,3 & 1 & 3,3 \\
\hline Total & 14 & 46,7 & 16 & 53,3 & 30 & 100,0 \\
\hline
\end{tabular}

\section{HASIL-HASIL PENELITIAN}

\section{1 Pengaruh Lingkungan Keluarga terhadap Persepsi Gender Mahasiswa Laki-}

\section{Laki dan Perempuan.}

Di lingkungan keluarga mahasiswa mendapatkan pendidikan gender melalui pendidikan orang tua terutama ibu karena ibu yang paling dekat dengan anak dari semenjak ia lahir dan dari proses pengasuhan dari ibu karena dari proses pengasuhanlah pendidikan gender diberikan. Besar kecilnya nilai gender yang diberikan di lingkungan keluarga bergantung dari kebersamaan antara ibu dengan mahasiswa. Semakin banyak kebersamaan mahasiswa dengan ibunya maka semakin banyak pula pendidikan gender yang mahasiswa terima dari ibunya yang berpendidikan tinggi.

Tabel 24 menunjukkan bahwa tingginya pendidikan gender yang diberikan di dalam lingkungan keluarga membuat tinggi pula persepsi gender mahasiswa baik mahasiswa laki-laki (46,7\%) maupun perempuan (53,3\%). Tabel 24 juga menunjukkan bahwa mahasiswa perempuan mendapatkan pendidikan gender dari ibu lebih banyak 
daripada laki-laki karena mahasiswa perempuan lebih sering mendapatkan pengasuhan dari ibu dibandingkan mahasiswa laki-laki. Hal ini disebabkan oleh bagi mahasiswa perempuan apabila mereka tidak memiliki kegiatan apapun di sekolah mereka lebih senang berada di rumah dengan ibu mereka dibandingkan pergi ke luar rumah dengan teman sehingga mahasiswa perempuan lebih banyak melakukan interaksi dengan ibu mereka, berbeda dengan mahasiswa laki-laki, apabila mereka tidak memiliki kegiatan sekolah mereka lebih senang pergi dengan teman daripada berada di rumah sehingga mahasiswa laki-laki memiliki waktu yang sedikit untuk berinteraksi dengan ibu mereka. Jadi mahasiswa perempuan lebih banyak mendapatkan pendidikan gender dari lingkungan keluarga dibandingkan laki-laki.

Tabel 24. Jumlah dan Persentase Lingkungan Keluarga dengan Jenis Kelamin dan Persepsi Gender Mahasiswa, Bogor 2010

\begin{tabular}{|c|c|c|c|c|c|c|c|}
\hline \multirow{2}{*}{$\begin{array}{c}\text { Persepsi Gender } \\
\text { Mahasiswa }\end{array}$} & \multicolumn{3}{|c|}{ Lingkungan Keluarga } & \multicolumn{2}{|c|}{ Total } \\
\cline { 3 - 8 } & \multicolumn{2}{|c|}{ Tinggi } & \multicolumn{2}{c|}{ Rendah } & \multicolumn{2}{c|}{} \\
\cline { 3 - 8 } & $\mathrm{n}$ & $\%$ & $\mathrm{n}$ & $\%$ & $\mathrm{n}$ & $\%$ \\
\hline \multirow{2}{*}{ Tinggi } & $\mathrm{L}$ & 14 & 46,7 & 0 & 0 & 14 & 46,7 \\
\cline { 2 - 8 } & $\mathrm{P}$ & 16 & 53,3 & 0 & 0 & 16 & 53,3 \\
\hline \multirow{2}{*}{ Rendah } & $\mathrm{L}$ & 0 & 0 & 0 & 0 & 0 & 0 \\
\cline { 2 - 8 } & $\mathrm{P}$ & 0 & 0 & 0 & 0 & 0 & 0 \\
\hline \multicolumn{2}{|c|}{ Total } & 30 & 100,0 & 0 & 0 & 30 & 100,0 \\
\hline
\end{tabular}

\subsection{Pengaruh Lingkungan Sekolah terhadap Persepsi Gender Mahasiswa Laki-Laki dan Perempuan.}

Lingkungan sekolah merupakan suatu kawasan tempat anak-anak diajarkan untuk mendapatkan, mengembangkan, dan menggunakan sumber-sumber dari keadaan sekitarnya. Sekolah yang merupakan tempat dimana pendidikan diterapkan dan diajarkan untuk memandang sesuatu secara objektif sesuai fakta-fakta yang ada, ternyata terdapat ketimpangan gender. Ada beberapa faktor di lingkungan sekolah yang menyebabkan ketimpangan gender yaitu pilihan bidang studi, nilai dan peran gender yang terdapat dalam buku ajar, dan nilai dan peran gender yang ditanamkan oleh guru.

Tabel 25 menunjukkan bahwa lingkungan sekolah memberikan pendidikan gender yang tinggi bagi mahasiswa laki-laki $(43,3 \%)$ dan perempuan $(53,4 \%)$ sehingga persepsi gender mahasiswapun juga tinggi, namun ternyata terdapat mahasiswa laki-laki $(3,3 \%)$ yang memiliki persepsi gender rendah padahal pendidikan gender yang ia terima dari lingkungan sekolah tinggi. Tingginya persepsi gender mahasiswa baik laki-laki maupun perempuan disebabkan oleh pendidikan yang mereka terima yang berupa pendidikan tentang ajaran pilihan bidang studi, pendidikan dari buku dan pendidikan dari guru, semuanya mengajarkan pendidikan yang tinggi gender atau pendidikan yang tidak membedakan kedudukan antara laki-laki dan perempuan. Dampak dari tingginya pendidikan gender yang mahasiswa terima dari sekolah membuat persepsi gender mahasiswa laki-laki dan perempuan juga tinggi.

Rendahnya persepsi gender mahasiswa laki-laki (3,3\%) padahal pendidikan gender yang ia terima dari lingkungan sekolah tinggi disebabkan oleh pergaulan mahasiswa lakilaki yang cukup luas. Mahasiswa laki-laki lebih banyak menghabiskan waktunya selain di lingkungan sekolah juga di lingkungan masyarakat dan di lingkungan keluarga. Pendidikan gender yang rendah ternyata mahasiswa dapatkan dari pergaulannya di masyarakat. Mahasiswa laki-laki berpegang teguh pada pendidikan gender yang dahulu ia 
dapatkan dari lingkungan masyarakatnya yaitu pendidikan yang rendah gender yang lebih mengutamakan laki-laki daripada perempuan sehingga berdampak pada rendahnya persepsi gender mahasiswa.

Tabel 25. Jumlah dan Persentase Lingkungan Sekolah dengan Jenis Kelamin dan Persepsi Gender Mahasiswa, Bogor 2010

\begin{tabular}{|l|c|c|c|c|c|c|c|}
\hline \multirow{2}{*}{$\begin{array}{c}\text { Persepsi Gender } \\
\text { Mahasiswa }\end{array}$} & \multicolumn{4}{|c|}{ Lingkungan Sekolah } & \multicolumn{2}{|c|}{ Total } \\
\cline { 3 - 8 } & \multicolumn{2}{|c|}{ Tinggi } & \multicolumn{2}{c|}{ Rendah } & \multicolumn{2}{c|}{} \\
\cline { 3 - 8 } & $\mathrm{n}$ & 13 & 43,3 & 0 & 0 & 13 & 43,3 \\
\hline \multirow{2}{*}{ Tinggi } & $\mathrm{P}$ & 16 & 53,4 & 0 & 0 & 16 & 53,4 \\
\hline \multirow{2}{*}{ Rendah } & $\mathrm{L}$ & 1 & 3,3 & 0 & 0 & 1 & 3,3 \\
\cline { 2 - 8 } & $\mathrm{P}$ & 0 & 0 & 0 & 0 & 0 & 0 \\
\hline \multicolumn{2}{|c|}{ Total } & 30 & 100,0 & 0 & 0 & 30 & 100,0 \\
\hline
\end{tabular}

6.3 Pengaruh Lingkungan Masyarakat terhadap Persepsi Gender Mahasiswa LakiLaki dan Perempuan.

Lingkungan masyarakat adalah suatu kawasan tempat sekelompok manusia yang secara relatif mandiri, hidup bersama-sama, memiliki kebudayaan yang sama, dan melakukan sebagian besar kegiatannya dalam kelompok tersebut. Salah satu penyebab ketimpangan gender di dalam lingkungan masyarakat adalah budaya. Menurut Purba (2005) ketimpangan gender selalu dihubungkan dengan perspektif ideologi patrilinial dan sosialisasi nilai dalam kehidupan rumah tangga. Akibatnya ideologi patrilinial tersebut tetap dapat mempertahankan ketimpangan gender dalam kehidupan masyarakat. Selain patrilinial, ideolagi matrilineal juga menyebabkan ketimpangan gender karena ideologi ini lebih mengutamakan perempuan dibandingkan laki-laki.

Selain budaya di dalam lingkungan masyarakat, mahasiswa juga akan dipengaruhi oleh teman sebayanya (peer group). Menurut Horton dan Hunt (1999) peer group adalah suatu kelompok dari orang-orang yang seusia dan memiliki status yang sama, dengan siapa seseorang umumnya berhubungan atau bergaul. Di mulai dari masa mahasiswa masih kecil hingga mereka dewasa. Melalui peer group mahasiswa akan belajar banyak hal diantaranya adalah budaya, status dan peranannya baik dalam kehidupan keluarga, sekolah maupun masyarakat.

Tabel 26 menunjukkan bahwa tingginya pendidikan gender yang diterima mahasiswa laki-laki $(41,4 \%)$ dan perempuan (55,2\%) di lingkungan masyarakat membuat tinggi pula persepsi gender mahasiswa, namun ada juga mahasiswa laki-laki $(3,4 \%)$ yang menerima pendidikan gender yang tinggi dari lingkungan masyarakat tetapi ternyata persepsi gendernya rendah dan ada pula mahasiswa laki-laki (100,0\%) yang menerima pendidikan gender yang rendah dari lingkungan masyarakat tetapi ternyata persepsi gendernya tinggi.

Rendahnya persepsi gender mahasiswa laki-laki (3,4\%) walaupun ia telah menerima pendidikan gender yang tinggi dari lingkungan masyarakat disebabkan oleh mahasiswa tersebut masih berpegang teguh pada pendidikan gender yang dahulu ia dapatkan dari lingkungan masyarakatnya. Lingkungan masyarakat dimana tempat ia bergaul saat ini merupakan lingkungan yang mengajarkan pendidikan gender yang tinggi, tetapi dahulu lingkungan masyarakatnya mengajarkan sebaliknya yaitu pendidikan yang rendah gender dan mahasiswa laki-laki tersebut masih berpegang teguh pada pendidikan 
gender yang dahulu yang ia terima yaitu pendidikan yang lebih mengutamakan laki-laki daripada perempuan.

Berbeda dengan mahasiswa laki-laki $(100,0 \%)$ yang mendapatkan pendidikan gender yang rendah, namun ternyata memiliki persepsi gender yang tinggi. Hal ini disebabkan oleh pergaulan mahasiswa dengan teman-temannya yang lebih banyak beranggapan bahwa kedudukan laki-laki dan perempuan merupakan suatu kedudukan yang seimbang dan hanya bergantung pada kemampuannya dalam melakukan sesuatu. Apabila perempuan bisa melakukan pekerjaan laki-laki dan sebaliknya apabila laki-laki bisa melakukan pekerjaan perempuan bukan suatu masalah yang harus diperdebatkan apabila mahasiswa laki-laki dan perempuan mampu melakukannya. Dampak dari pergaulan mahasiswa laki-laki dengan temannya, rendahnya pendidikan gender yang mahasiswa terima tidak mempengaruhi persepsi gendernya tetapi persepsi gender mahasiswa lebih banyak dipengaruhi oleh pergaulannya teman-teman mahasiswa.

Tabel 26. Jumlah dan Persentase Lingkungan Masyarakat dengan Jenis Kelamin dan Persepsi Gender Mahasiswa, Bogor 2010

\begin{tabular}{|c|c|c|c|c|c|c|c|}
\hline \multirow{3}{*}{\multicolumn{2}{|c|}{$\begin{array}{l}\text { Persepsi Gender } \\
\text { Mahasiswa }\end{array}$}} & \multicolumn{4}{|c|}{ Lingkungan Masyarakat } & \multirow{2}{*}{\multicolumn{2}{|c|}{ Total }} \\
\hline & & \multicolumn{2}{|c|}{ Tinggi } & \multicolumn{2}{|c|}{ Rendah } & & \\
\hline & & $\mathrm{n}$ & $\%$ & $\mathrm{n}$ & $\%$ & $\mathrm{n}$ & $\%$ \\
\hline \multirow[t]{2}{*}{ Tinggi } & $\mathrm{L}$ & 12 & 41,4 & 1 & 100,0 & 13 & 43,3 \\
\hline & $\mathrm{P}$ & 16 & 55,2 & 0 & 0 & 16 & 53,3 \\
\hline \multirow[t]{2}{*}{ Rendah } & $\mathrm{L}$ & 1 & 3,4 & 0 & 0 & 1 & 3,3 \\
\hline & $\mathrm{P}$ & 0 & 0 & 0 & 0 & 0 & 0 \\
\hline \multicolumn{2}{|c|}{ Total } & 29 & 100,0 & 1 & 100,0 & 30 & 100,0 \\
\hline
\end{tabular}

\subsection{Perbedaan Faktor yang Mempengaruhi Persepsi Gender Mahasiswa Laki-laki dan Perempuan.}

Persepsi gender adalah proses yang digunakan untuk mencoba mengetahui, memahami dan memberikan penilaian tentang peran antara laki-laki dan perempuan dalam lingkungannya. Mengetahui, memahami dan memberikan penilaian di sini maksudnya adalah suatu proses aktivitas seseorang dalam memberikan kesan, penilaian, pendapat, merasakan dan menginterpretasikan sesuatu berdasarkan informasi yang ditampilkan dari sumber lain mengenai peran laki-laki dan perempuan dalam lingkungannya.

Persepsi gender di dalam lingkungan keluarga dipengaruhi oleh pendidikan orang tua dan proses pengasuhan yang dilakukan oleh orang tua dalam memberikan pendidikan kepada mahasiswa terutama ibu, karena ibu merupakan orang yang paling dekat dengan mahasiswa dan orang yang paling utama dalam memberikan pendidikan kepada mahasiswa di dalam lingkungan keluarga. Di lingkungan sekolah orang yang paling utama memberikan pendidikan gender kepada mahasiswa adalah guru sedangkan di lingkungan masyarakat orang yang paling utama dalam memberikan pendidikan gender atau yang paling berpengaruh terhadap persepsi gender mahasiswa adalah temantemannya. 
Tabel 27. Jumlah dan Persentase Orang yang Mempengaruhi Persepsi Gender Mahasiswa dengan Jenis Kelamin dan Persepsi Gender Mahasiswa,

Bogor 2010

\begin{tabular}{|c|c|c|c|c|c|c|c|}
\hline \multirow{3}{*}{\multicolumn{2}{|c|}{ Persepsi Gender Mahasiswa }} & \multicolumn{4}{|c|}{$\begin{array}{c}\text { Orang yang Mempengaruhi Persepsi } \\
\text { Gender Mahasiswa } \\
\end{array}$} & \multirow{2}{*}{\multicolumn{2}{|c|}{ Total }} \\
\hline & & \multicolumn{2}{|c|}{ Ibu } & \multicolumn{2}{|c|}{ Teman } & & \\
\hline & & $\mathrm{n}$ & $\%$ & $\mathrm{n}$ & $\%$ & $\mathrm{n}$ & $\%$ \\
\hline \multirow{2}{*}{ Tinggi } & $\mathrm{L}$ & 5 & 31,2 & 9 & 64,3 & 14 & 46,7 \\
\hline & $\mathrm{P}$ & 11 & 68,8 & 5 & 35,7 & 16 & 53,3 \\
\hline \multirow{2}{*}{ Rendah } & $\mathrm{L}$ & 0 & 0 & 0 & 0 & 0 & 0 \\
\hline & $\mathrm{P}$ & 0 & 0 & 0 & 0 & 0 & 0 \\
\hline \multicolumn{2}{|c|}{ Total } & 16 & 100,0 & 14 & 100,0 & 30 & 100,0 \\
\hline
\end{tabular}

Tabel 27 menunjukkan bahwa bagi mahasiswa laki-laki (64,3\%) orang yang paling berpengaruh terhadap persepsi gendernya adalah teman-teman mahasiswa. Berbeda dengan mahasiswa perempuan (68,8\%) yang ternyata paling banyak mempengaruhi persepsi gendernya adalah ibu mahasiswa. Tingginya pengaruh ibu terhadap persepsi gender mahasiswa perempuan disebabkan oleh sejak dahulu mahasiswa perempuan lebih banyak menghabiskan waktu untuk berada di rumah bersama ibu mereka apabila mereka tidak memiliki kegiatan di sekolah sehingga mahasiswa perempuan lebih banyak melakukan interaksi dengan ibu mereka. Sebaliknya untuk mahasiswa laki-laki, mereka lebih banyak pergi bersama teman-temannya daripada berada di rumah apabila mereka tidak memiliki kegiatan di sekolah sehingga mahasiswa laki-laki kurang melakukan interaksi dengan ibu mereka.

Tabel 28 menunjukkan bahwa 52,6 persen tingginya persepsi gender mahasiswa laki-laki dipengaruhi oleh guru sedangkan untuk mahasiswa perempuan tingginya persepsi gender yang dipengaruhi oleh guru hanya 42,1 persen. Mahasiswa laki-laki lebih sering menghabiskan waktunya di lingkungan sekolah dan masyarakat sehingga yang lebih banyak mempengaruhi persepsi gender laki-laki adalah lingkungan sekolah yang banyak dipengaruhi oleh guru dan lingkungan masyarakat yang banyak dipengaruhi oleh teman-temannya. Berbeda dengan perempuan yang lebih banyak dipengaruhi oleh lingkungan keluarga yaitu ibu walaupun mereka telah sering bergaul dengan lingkungan sekolah dan masyarakat. Jadi faktor yang paling mempengaruhi persepsi gender mahasiswa laki-laki adalah lingkungan sekolah (guru) dan lingkungan masyarakat (teman) sedangkan bagi mahasiswa perempuan lingkungan keluargalah (ibu) yang paling mempengaruhi persepsi gendernya.

Tabel 28. Jumlah dan Persentase Pengaruh Guru dengan Jenis Kelamin dan Persepsi Gender Mahasiswa, Bogor 2010

\begin{tabular}{|c|c|c|c|c|c|c|c|}
\hline \multirow{3}{*}{\multicolumn{2}{|c|}{$\begin{array}{l}\text { Persepsi Gender } \\
\text { Mahasiswa }\end{array}$}} & \multicolumn{4}{|c|}{$\begin{array}{c}\text { Pengaruh Guru terhadap Persepsi } \\
\text { Gender Mahasiswa }\end{array}$} & \multirow{2}{*}{\multicolumn{2}{|c|}{ Total }} \\
\hline & & \multicolumn{2}{|c|}{ Tinggi } & \multicolumn{2}{|c|}{ Rendah } & & \\
\hline & & $\mathrm{n}$ & $\%$ & $\mathrm{n}$ & $\%$ & $\mathrm{n}$ & $\%$ \\
\hline \multirow{2}{*}{ Tinggi } & $\mathrm{L}$ & 10 & 52,6 & 2 & 18,2 & 12 & 40,0 \\
\hline & $\mathrm{P}$ & 8 & 42,1 & 4 & 36,3 & 12 & 40,0 \\
\hline \multirow[t]{2}{*}{ Rendah } & $\mathrm{L}$ & 1 & 5,3 & 1 & 9,1 & 2 & 6,7 \\
\hline & $\mathrm{P}$ & 0 & 0 & 4 & 36,4 & 4 & 13,3 \\
\hline \multicolumn{2}{|c|}{ Total } & 19 & 100,0 & 11 & 100,0 & 30 & 100,0 \\
\hline
\end{tabular}




\subsection{Kesimpulan}

\section{KESIMPULAN DAN SARAN}

Persepsi gender mahasiswa ternyata tidak dipengaruhi oleh lingkungan keluarga karena mahasiswa ketika mulai beranjak dewasa tidak bersama orang tuanya khususnya ibu yang biasanya selalu mengasuh dan mendidik mahasiswa sedari kecil. Waktu 15 tahun pengasuhan ibu dikalahkan oleh waktu 5 tahun ketika mahasiswa tidak lagi bersama ibu, karena bersekolah jauh dari rumah. Pendidikan gender yang diterima mahasiswa dari ibunya tidak berpengaruh banyak terhadap persepsi gender mahasiswa. Begitu juga dengan budaya baik itu sistem patrilinial maupun sistem matrilinial tidak berpengaruh pada persepsi gender mahasiswa karena mahasiswa pada umumnya memiliki orang tua dari daerah yang berbeda sehingga sistem parental dimana garis keturunan berasal dari ayah dan ibu yang lebih dominan dalam lingkungan keluarga mahasiswa.

Secara umum persepsi gender mahasiswa lebih banyak dipengaruhi oleh keberadaan mereka di lingkungan sekolah dan pergaulan mereka dengan teman sebayanya (peer group) di lingkungan masyarakat, tetapi terdapat perbedaan faktor yang mempengaruhi persepsi gender mahasiswa laki-laki dan perempuan. Mahasiswa laki-laki lebih banyak dipengaruhi oleh guru yang ada di lingkungan sekolah dan pergaulannya dengan teman di lingkungan masyarakat dalam berpersepsi tentang perbedaan kedudukan antara laki-laki dan perempuan. Berbeda dengan mahasiswa perempuan yang lebih banyak dipengaruhi oleh ibu mereka dalam berpersepsi tentang kedudukan antara lakilaki dan perempuan.

Perbedaan faktor yang mempengaruhi mahasiswa laki-laki dan perempuan disebabkan oleh adanya perbedaan waktu yang dihabiskan mahasiswa laki-laki dan perempuan dalam lingkungan keluarga, sekolah dan masyarakat. Mahasiswa perempuan lebih banyak menghabiskan waktu mereka bersama dengan ibu mereka di lingkungan keluarga sehingga mahasiswa perempuan lebih banyak melakukan interaksi dengan ibu mereka dibandingkan laki-laki sehingga pendidikan gender mahasiswa perempuan pun lebih banyak mereka terima dari ibu. Sebaliknya dengan mahasiswa laki-laki, mereka lebih banyak menghabiskan waktunya untuk berinteraksi dengan guru mereka di sekolah dengan mengikuti berbagai kegiatan sekolah dan pergi dengan teman-teman mereka dibandingkan bersama dengan ibu mereka sehingga pendidikan gender lebih banyak mahasiswa laki-laki dapatkan dari teman mereka.

\subsection{Saran}

Penelitian ini dilakukan di sebuah perguruan tinggi islam (STEI TAZKIA) dengan pemilihan responden khusus yang mempunyai ibu yang telah mengenyam pendidikan tinggi. Lebih bagus lagi apabila penelitian ini bersifat membandingkan antara perguruan tinggi umum dengan perguruan tinggi khusus seperti STEI TAZKIA sehingga bisa melihat perbedaan persepsi gender responden antara dua buah perguruan tinggi tersebut. Selain itu baik juga jika melakukan penelitian dengan membandingkan dua perguruan tinggi umum dan khusus dengan pengambilan responden yang mempunyai ibu yang hanya mengenyam pendidikan rendah sehingga bisa dibandingkan perbedaan pendidikan gender yang diterima responden di dalam keluarga antara ibu yang mengenyam pendidikan tinggi dan ibu yang mengenyam pendidikan rendah. Penelitian tersebut kemungkinan akan menghasilkan perbedaan persepsi gender mahasiswa. Perbedaan ini bisa jadi berasal dari perbedaan pengasuhan yang diterima mahasiswa baik mahasiswa 
yang berasal dari ibu yang telah mengenyam pendidikan tinggi maupun mahasiswa yang berasal ibu yang hanya mengenyam pendidikan rendah.

\section{DAFTAR PUSTAKA}

Ahmadi, Abu. 2004. Sosiologi Pendidikan. Rineka Citra : Jakarta.

Baron, Robert A. dan Donn Byrne. 2005. Psikologi Sosial. Jilid ke dua. Erlangga : Jakarta.

Dewi, Ika Sari. 2006. Kesiapan Menikah pada Perempuan Dewasa Awal yang Bekerja. www.library.usu.ac.id. Diakses tanggal 25 Februari 2010 .

Eliyani, 2009. Meningkatkan Keterlibatan Perempuan Dalam Pendidikan Bidang Sains Dan Teknologi. www.mercubuana.ac.id. Diakses tanggal 18 Desember 2009.

Handayani, Trisakti dan Sugiarti. 2008. Konsep dan Teknik Penelitian Gender. UMM Press : Malang.

Hartaji, R. Damar Hadi. 2009. Motivasi Berprestasi Pada Mahasiswa Yang Berkuliah Dengan Jurusan Pilihan Orang Tua. www.gunadarma.ac.id. Diakses tanggal 21 Oktober 2010.

Hasibuan, Chrysanti dan Sedyono. 1996. Perempuan Di Sektor Formal “ Kerja Ya, Karier Tidak ”. Dipaparkan dalam Kumpulan Tulisan Indonesia Dulu Dan Kini. Jakarta

Hastuti, Dwi. 2008. Pengasuhan : Teori dan Prinsip serta Aplikasinya Di Indonesia. Departemen Ilmu Keluarga dan Konsumen, FEMA, IPB : Bogor.

Horton, Paul .B dan Chester .L.Hunt. 1999. Sosiologi. Edisi keenam. Erlangga : Jakarta.

Ihromi, Tapi Omas. 1990. Laporan Penelitian : Para Ibu Yang Berperan Tunggal Dan Yang Berperan Tinggi. Fakultas Ekonomi, Universitas Indonesia : Jakarta.

Lestari, Rizqi Suci. 2008. Persepsi Remaja Terhadap Pembagian Peran Gender Dalam Kelurga. Skripsi. Program Sarjana IPB : Bogor.

Najah, Athiyyatun. 2007. Hubungan Antara Persepsi Anak Terhadap Pola Asuh Orang

Tua Dengan Motivasi Belajar. Fakultas Psikologi, Universitas Muhammadiyah

Surakarta : Surakarta.

Purba, Jonni. 2005. Ketimpangan Gender dan Bertahannya Konstruksi Patriarkhi dalam Masyarakat Karo. Dipaparkan dalam Etnovisi, Jurnal Sosial Budaya, Edisi 01, Tahun I, Juni 2005.

Rahayu, Maria Dewi. 2009. Pola Asuh Anak Ditinjau dari Aspek Relasi Gender. Skripsi. Program Sarjana IPB : Bogor.

Rahmawati, Ade. 2006. Motivasi Berprestasi Mahasiswa Ditinjau dari Pola Asuh. Program Studi Psikologi. Fakultas Kedokteran. Universitas Sumatra Utara : Medan.

Sarwono, Jonathan. 2006. Metode Penelitian Kuantitatif dan Kualitatif. Graha Ilmu : Yogyakarta.

Semiawan, Conny R. 1999. Pendidikan Tinggi : Peningkatan Kemampuan Manusia Sepanjang Hayat Seoptimal Mungkin. Direktorat Jendral Pendidikan Tinggi. Departemen Pendidikan dan Kebudayaan : Jakarta.

Singarimbun, M dan Sofyan Effendi. 1989. Metode Penelitian Survei. LP3ES : Jakarta.

Sudarta, Wayan. 2008. Ketimpangan Gender Di Bidang Pendidikan. http://ejournal.unud.ac.id/abstrak/ketimpangan\%20gender.pdf. [diakses tanggal 14 Desember 2009]. 
Taher, Alwin. 2009. Persepsi Mahasiswa terhadap Kesadaran Gender. Skripsi. Program Sarjana IPB : Bogor.

Wiliam, de Vries Dede. 2006. Gender Bukan Tabu : Catatan Perjalanan Fasilitasi Kelompok Perempuan Di Jambi. CIFOR : Bogor.

Wulandari, Astuti. 2009. Analisis Persepsi Gaya Pengasuhan Orang Tua, Keterampilan Sosial, Prestasi Akademik, dan Self-Esteem Mahasiswa Tingkat Persiapan Bersama (TPB) Institut Pertanian Bogor. Skripsi. Program Sarjana IPB : Bogor. 